\title{
Primární hyperoxalurie
}

\author{
MUDr. Dagmar Uvírová \\ Dětské oddělení KNTB, a.s., Zlín
}

Předkládáme kazuistiku 4,5leté dívky, která byla přijata na naše oddělení pro infekci močových cest. Překvapivý nález hyperechogenních papil na UZ ledvin vedl k rozšíření vyšetření a nakonec k diagnóze primární hyperoxalurie 1. typu.

Klíčová slova: primární hyperoxalurie, infekce močových cest, urolitiáza, konečné stadium ledvinového onemocnění.

\section{Primary hyperoxaluria}

We present a case study of a 4,5-year-old girl admitted to our departement for urinary tract infection. Surprising ultrasonographic finding of renal hyperechogenity lead to further examination and finally primary hyperoxaluria type 1 was diagnosed.

Key words: primary hyperoxaluria, urinary tract infection, urolithiasis, end-stage renal disease.

\section{Úvod}

Primární hyperoxalurie je vzácná recesivně dědičná porucha glyoxylátového metabolizmu, vedoucí k nadprodukci oxalátu, jeho zvýšenému vylučování ledvinami, urolitiáze a nefrokalcinóze, následně k jeho ukládání do tkání a extrarenální manifestaci choroby.

\section{Kazuistika}

4,5letá dívka byla prijiata na naše oddělení pro febrilie, bolesti hlavy. Do té doby byla zdravá, pouze hraničně prospívající, hmotnostně na 3. percentilu (viz tab. 1). Klinický nález byl při príijmu chudý, ameningeální, v laborato-

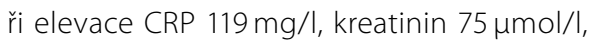
leukocytóza 13,6; $10^{9}$ jinak $\vee$ normě. $\vee$ moči byl diagnostikován pyurický nález, zahájena proto intravenózní antibiotická terapie Axetinem, kultivačně $v$ moči byla prokázána $E$. coli haemolytica $>10^{5}$ citlivá na podávaná ATB. Na ultrazvuku ledvin bylo popsáno zvětšení a edematózní prosáknutí parenchymu levé ledviny, překvapivě i hyperechogenita papil oboustranně (viz obr. 1). V kontrolní laboratoři byl pokles zánětlivých parametrů, kontrolní kultivace moče opakovaně sterilní, na UZ ledvin

Obr. 1. Hyperechogenní ledvinný parenchym a papily na UZ při první hospitalizaci

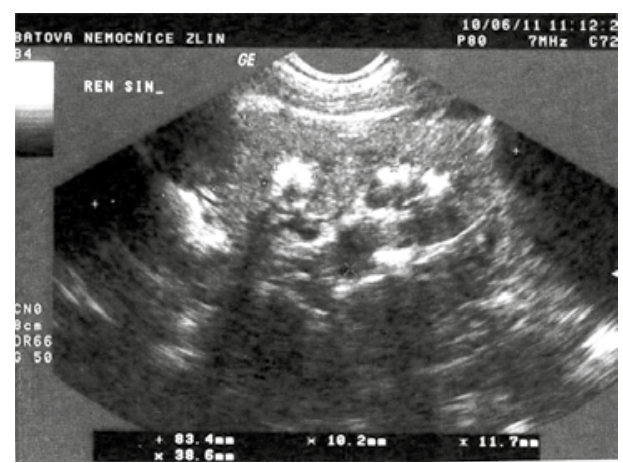

před propuštěním přetrvávaly hyperechogenní papily. Pro podezření na poruchu kalciového metabolizmu byl odebrán jednorázový vzorek moče na screening urolitiázy, matka však žádala propuštění do ambulantní péče ještě před obdržením výsledků. Dívka tedy byla propuštěna s terapií Zinnat sir., doporučeny kontroly moče a klinického stavu obvodním lékařem, další došetření cestou nefrologické ambulance.

Po týdnu v domácí péči, kdy byla dívka unavená, subfebrilní, přichází k rehospitalizaci pro febrilie, bolesti břicha. V laboratoři opět elevace zánětlivých parametrů, CRP 157,4mg/l. V moči pyurie, proto zahájena ATB léčba Gentamicinem. Kultivačně byla v moči prokázána Klebsiella pne-

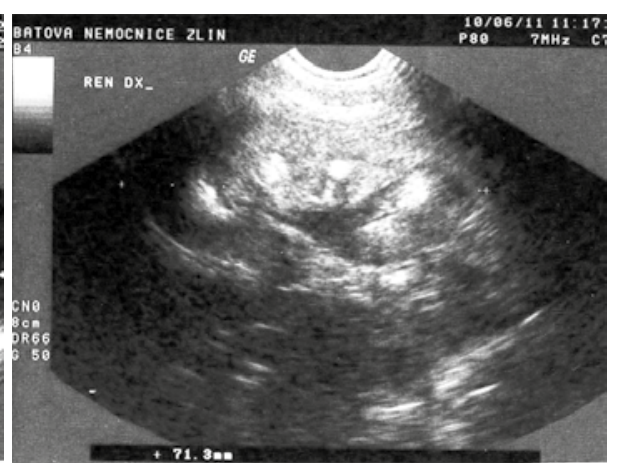

umoniae, kmen s širokou produkcí betalaktamáz, citlivá na Gentamicin. V jednorázovém vzorku moče odebraném při předcházející hospitalizaci byla zjištěna výrazná hyperoxalurie 1,72 mmol//, poměr oxaláty/kreatinin 0,782. Na UZ ledvin oboustranně hyperechogenní parenchym, redukován vpravo na $6 \mathrm{~mm}$, vlevo na 7,6 mm, navíc známky levostranné pyelonefritidy a nově dilatace KPS vlevo (viz obr. 2). Pro podezření na urolitiázu jsme doplnili nativní rtg snímek břicha, kde byly popsány mnohočetné kalcifikace projikující se do stínů obou ledvin. Navíc vlevo podél SI skloubení se zobrazoval řetízkovitý stín, v.s. 3 urolity průměru 4-5 mm (viz obr. 3). Hladiny Ca, P, Mg v séru i parathormon byly $v$ normě.
KORESPONDENČNÍ ADRESA AUTORA: MUDr. Dagmar Uvírová, dagmar.uvirova@email.cz Dětské oddělení KNTB, a.s.

Havlíčkovo nábř. 600, 76275 Zlín
Cit. zkr: Pediatr. praxi. 2016; 17(2): 105-108

Článek príijat redakcí: 7. 11. 2015

Článek přijat k publikaci: 25. 1. 2016 
Tab. 1. Růstový grafpacientky

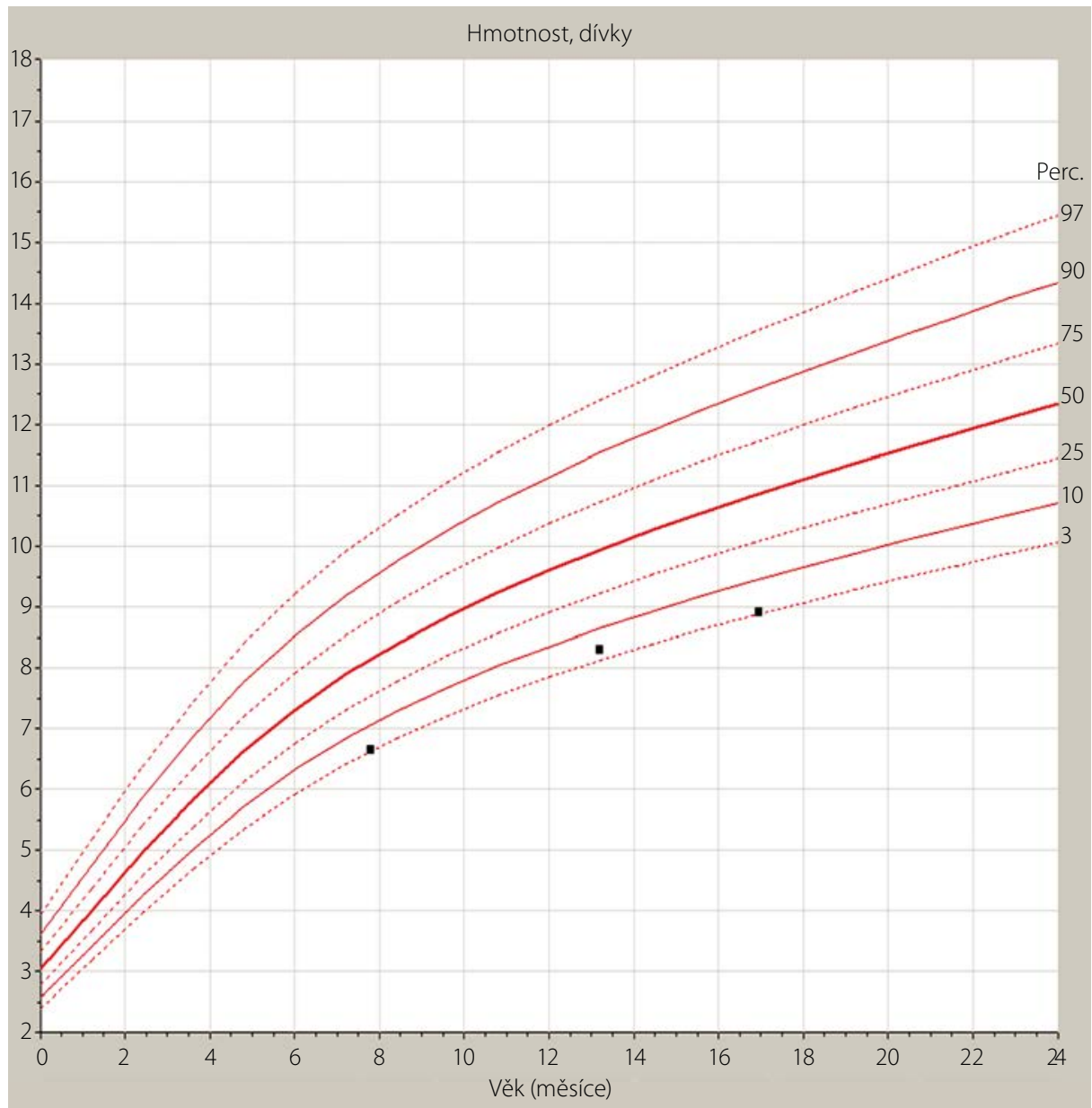

Vzhledem k podezření na hyperoxalurii jsme zahájili podávání pyridoxinu. V laboratoři však docházelo ke zhoršování parametrů ledvinných funkcí (viz tab. 2), bilance tekutin vyrovnaná, diuréza $3,7 \mathrm{ml} / \mathrm{kg} / \mathrm{h}$, glomerulární filtrace dle cystatinu $\mathrm{C} 0,62 \mathrm{ml} / \mathrm{s} / 1,73 \mathrm{~m}^{2}$, proto byla dívka po třech dnech hospitalizace preložena $k$ dalšímu došetření na vyšší pracoviště.

Zde bylo doplněno nativní CT ledvin s nálezem dřeňových kalcifikací charakteru nefroklacinózy, mírné levostranné dilatace KPS vlevo (viz obr. 4, 5). Rtg hrudníku bez kalcifikací, echokardiografie s normálním nálezem. Bylo pokračováno v ATB terapii, při které poklesly zánětlivé parametry. Vzhledem k tomu, že byla na našem pracovišti zahájena terapie Pyridoxinem, byl 24hod. sběr moče na litogenní soubor tímto ovlivněn, proto byla pacientka konzultována na zahraničním pracovišti (Mayo Clinic) a bylo schváleno genetické vyšetření jako rozhodující pro určení diagnózy. V průběhu druhého týdne hospitalizace byl opakovaně v moči nález drobných konkrementů, biochemicky oxalátová litiáza. V laboratoři přetrvával stacionární nález zhoršené glomerulární filtrace, hyperazotémie, pokles oxalurie na 0,92 $\mathrm{mmol} / \mathrm{l}$.

Dívka byla propuštěna do domácí péče s testrava bez oxalátů. U pacientky byla geneticky byla stacionární, CHRI II. stupně s postupnou progresí, od 10/2013 byla dialyzována a zařazena na waiting list k transplantaci. V lednu 2014 byla provedena úspěšná kombinovaná transplantace jater a ledviny ve FN Motol.

\section{Diskuze}

Primární hyperoxalurie (PH) je vzácná autosomálně recesivně dědičná porucha glyoxylátového metabolizmu, vedoucí k nadprodukci oxalátu a jeho ukládání jako štavelanu vápenatého do tkání, predispozičně ledvin $(1,2)$.

$\mathrm{PH}$ 1. typu je dána deficitem jaterní peroxysmální alanin-glyoxylát aminotransferázy, která konvertuje glyoxylát na glycin. To vede ke zvýšení poolu glyoxylátu a nadprodukci oxalátu. Gen kódující alanin-glyoxylát aminotransferázu je lokalizován na krátkém raménku 2. chromozomu, je známo asi 150 mutací (3), rapií Pyridoxinem a Vitar sodou k alkalizaci moče, potvrzena hyperoxalurie I. typu, hyperazotemie
Obr. 2. Dilatace dutého systému a redukce parenchymu levéledviny pri rehospitalizaci

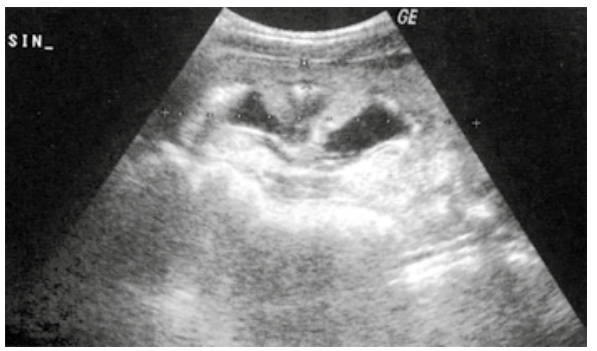

Obr. 3. Prostýrtg snímek bricha s mnohočetnými kalcifikacemi

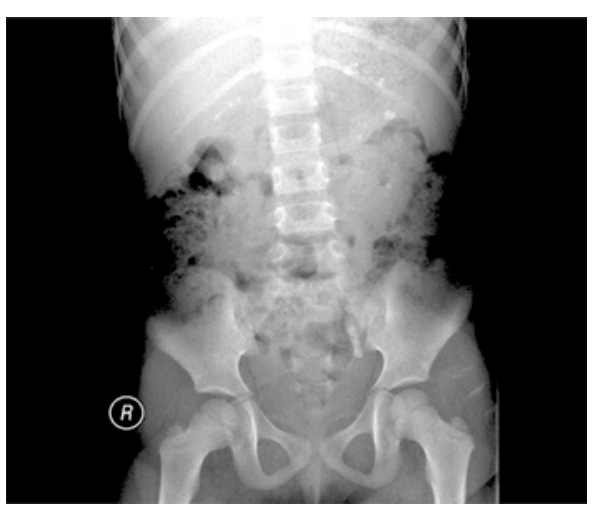

což vede ke třem rưzným variantám aktivity enzymu (4):

- absence imunoreaktivního proteinu a jeho katalytické aktivity,

- prítomnost imunoreaktivního proteinu a absence jeho katalytické aktivity,

- prítomnost imunoreaktivního proteinu a jeho aktivity, ale lokalizované v mitochondriích, ne peroxisomech - mistargeting.

Nadbytek oxalátu je vylučován ledvinami, exkrece přesahuje $1 \mathrm{mmol} / 1,73 \mathrm{~m}^{2} / 24$ hod (norma< 0,5 mmol/1,73 m²/24 hod.), dochází k agregaci krystalů kalcium oxalátu, urolitiáze a nefrokalcinóze. S pokračujícím poškozením ledvin klesá glomerulární filtrace, poklesne-li pod 30-40 ml/min/1,73 m², dochází k ukládání oxalátu do tkání (sítnice, myokard, kůže, kosti...), což vede k extrarenální manifestaci choroby (6).

Renální manifestace může mít několik podob $(1,7)$ :

- infantilní oxalóza (26\%) - k projevům nefrokalcinózy a poruše renálních funkcí dochází v prvních 6 měsících života dítěte

- opakovaná urolitiáza (30\%) - u dětí jsou symptomy spojeny s urolitiázou: hematurie, renální kolika, IMC, vzácně akutní renální selhání při oboustranné obstrukci 
- náhodně zjištěná urolitiáza $\vee$ dospělosti (30\%)

- diagnóza po selhání štěpu po transplantaci ledviny (10\%)

- diagnóza při screeningu v rodině (13\%)

Projevy systémové oxalózy $(1,6)$ závisí na tkáni, v níž dochází k ukládání kalcium oxalátu:

- myokard-poruchy převodní činnosti, které mohou vést až k zástavě srdce

- cévy - porucha periferního prokrvení vedoucí ke gangrénám, často komplikuje vytvoření shuntu pro hemodialýzu

- klouby - synovitida, omezení hybnosti, bolest

- sítnice-ukládání depozit vede ke zhoršení visu

- hypotyreóza

- periferní neuropatie

- kůže - livedo reticularis, calcinosis cutis metastatica

K diagnóze tedy vede opakovaná kalciumoxalátová urolitiáza (1, 9), případně nefrokalcinóza, významná hyperoxalurie při absenci onemocnění GIT, nadměrného príjmu oxalátu Či vitaminu C. V laboratoři potom hyperoxalurie $>1$ mmol/1,73 m²/24 hod., zvýšený poměr oxalát/kreatinin $v$ moči, jehož fyziologické hodnoty se mění s věkem, a zvýšená exkrece glykolátu $\checkmark$ moči (6). Na UZ ledvin je hyperechogenní parenchym, př́padně urolity, které je možno diagnostikovat i na prostém rtg snímku břicha. Definitivním potvrzením diagnózy je potom genetické vyšetření $(4,8)$.

Diferenciálně diagnosticky je třeba odlišit jiné poruchy glyoxylátového metabolizmu, zvýšený prríjem oxalátů ve stravě (čokoláda, kakao, rebarbora, špenát, černý čaj, ořechy. . .), zvýšenou střevní absorpci při malabsorpci tuků (cystická fibróza, syndrom krátkého střeva). Raritně potom absenci Oxalobacter formigenes, bakterie, která ve střevě degraduje oxalát (10).

Úspěšnost léčby závisí na časné diagnóze, která umožňuje oddálit konečné stadium ledvinového onemocnění a extrarenální manifestaci $(1,9)$. Důležitý je zvýšený príijem tekutin (> 31/1,73 m²/24 hod.), který snižuje koncentraci kalcium oxalátu $v$ primární moči a jeho ukládání do intersticia ledvin. Dále je třeba omezit potraviny s vysokým obsahem oxalátu (viz výše). Ve farmakoterapii mají přední místo vysoké dávky pyridoxinu (6). Pyridoxin je koenzymem alanin-glyoxylát
Tab. 2. Vývoj laboratorních výsledkủ během hospitalizací na našem pracovišti

\begin{tabular}{|l|c|c|c|c|}
\hline Datum & 4.6. & 10.6. & 17.6. & 21.6. \\
\hline urea mmol/l & 6,3 & & 12,7 & 13,7 \\
\hline kreatinin umol/l & 75 & & 152 & 185 \\
\hline kyselina močová umol/l & 507 & & 540 & 450 \\
\hline CRP mgl// & 109 & 14,1 & 157 & 88 \\
\hline
\end{tabular}

Obr. 4. Nativní CT břicha s mnohočetnými urolity (snímky poskytnuty s laskavostí MUDr. Lucie Horáčkové, Klinika dětské radiologie, FN Brno)
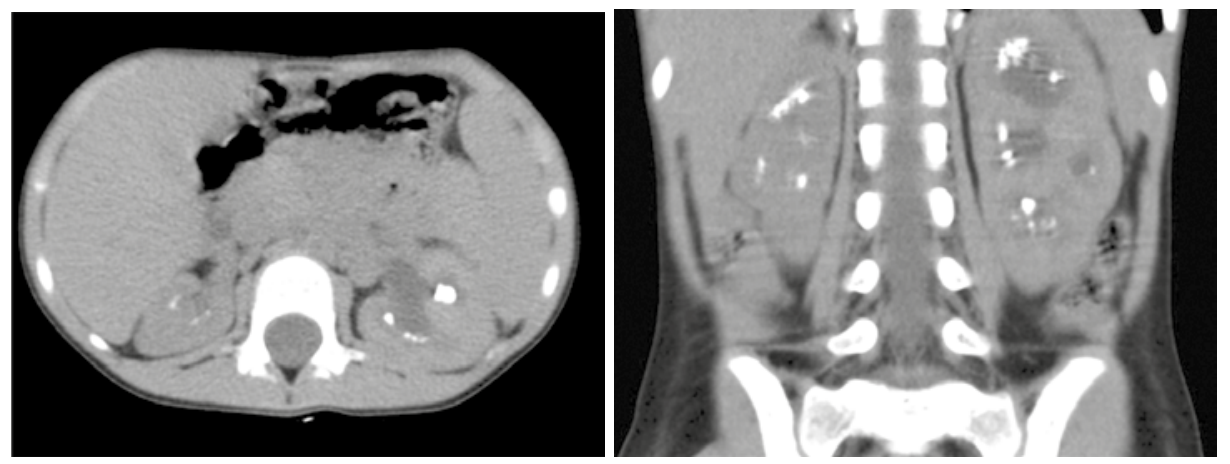

aminotransferázy, která konvertuje glyoxylát na glycin namísto oxalátu. Asi $30 \%$ pacientů s PH1 reaguje na terapii pyridoxinem, tato léčba by tedy měla být zahájena u všech po dobu 3-6 měsíců. Počáteční dávka je 5 mg/ kg/den, není-li adekvátní odpovědi, potom je možno dávky zvyšovat až na 20 mg/kg/ den. Terapie je ukončena, pokud není signifikantní pokles oxalurie. Infekce močových cest léčit dle citlivosti s ohledem na prípadnou nefrotoxicitu podávaných antibiotik a její možný podíl na progresi renální insuficience, dle možností pracoviště vhodná monitorace sérových hladin ATB. Alkalizace moče inhibuje precipitaci kalciumoxalátu, používá se kalium chlorid (0,15 g/kg/den), magnesium (500 mg/ $\mathrm{m}^{2} /$ den). Urologická intervence je indikována při obstrukci kamenem, nejčastěji je provedena nefrostomie či zaveden stent. U naší pacientky nebylo vzhledem ke spontánnímu odchodu konkrementů a zlepšení UZ nálezu na vyšším pracovišti k urologické intervenci přistoupeno.

Konvenční hemodialýza nevede k dostatečné eliminaci oxalátu (max. 950-1440 $\mu$ mol/den, zatímco produkce oxalátu je 3500-7500 umol/den). Intenzivní hemodialýza se provádí před transplantací ke snížení plasmatické hladiny oxalátu. Transplantace jater je jedinou kurativní metodou PH1 (11). Vzhledem k tomu, že pacienti mají většinou konečné stadium ledvinového onemocnění, preferuje se kombinovaná transplantace jater a ledvin. Druhou možností je transplantace jater, následovaná v druhé době transplantací ledvin.
Odstranění depozit kalcium oxalátu z tkání po úspěšné transplantaci může trvat i více než 2 roky.

Primární hyperoxalurie 2. typu má většinou mírnější průběh než PH1 (6). Je dána deficitem glyoxylát reduktázy/hydroxypyruvát reduktázy, která není prítomna pouze v játrech. Vede ke zvýšenému vylučování glyoxylátu a hydroxypyruvátu, tyto jsou konvertovány na oxalát a kyselinu L-glycerovou. Patognomické je zvýšené vylučování L-glycerátu močí, zatímco u PH1 je typické zvýšené vylučování glykolátu (12). V terapii se uplatňuje zvýšený prríjem tekutin, alkalizace moče, pyridoxin je vzhledem k patogenezi bez efektu. Konečné stadium ledvinového onemocnění není u $\mathrm{PH} 2$ časté, pokud k němu pacient dospěje, je indikována transplantace ledvin.

Primární hyperoxalurie 3. typu je způsobena defektem zatím neobjasněného genu lokalizovaného na 10. chromozomu. Mohlo by se jednat o defekt 4-hydroxy-2-oxoglutarát aldolázy, která katalyzuje přeměnu oxalátu na hydroxyprolin $(1,3)$.

\section{Závěr}

Nález hyperechogenního parenchymu při UZ vyšetření ledvin u dětí je překvapivým, ne však zrídkavým nálezem, jenž vyžaduje došetření dalšími zobrazovacími metodami a je-li potvrzen, důkladné vyšetření etiologie. To u naší pacientky vedlo k vzácné diagnóze, kterou se, po 2,5 letech symptomatické terapie, podařilo vyřešit kauzálně kombinovanou transplantací jater a ledvin. 


\section{SDĚLENII Z PRAXE}

PRIMÁRNÍ HYPEROXALURIE

\section{LITERATURA}

1. Watts RW. Primary hyperoxaluria type I. QJM 1994; 87: 593. 2. Cochat P. Primary hyperoxaluria type 1. Kidney Int 1999; 55: 2533.

3. Danpure CJ, Jennings PR, Fryer P, et al. Primary hyperoxaluria type 1: genotypic and phenotypic heterogenity. J Inherit Matyb Dis 1994; 17: 487.

4. Danpure CJ. Advances in the enzymology and molecular genetics of primary hyperoxaluria type 1. Prospects for gene therapy. Nephrol Dial transplant 1995; 10 Suppl 8: 24. 5. Seargeant $L E$, deGroot GW, Dilling LA, et al. Primary oxaluria type 2 (L-glyceric aciduria): a rare cause of nephrolithiasis in children. J Pediatr 1991; 118: 912
6. Hoppe B, Beck BB, Milliner DS. The primary hyperoxalurias. Kidney Int 2009; 75: 1264

7. Cochat P, Koch Nogueira PC, Mahmoud MA, et al. Primary hyperoxaluria in infants: medical, ethical, and economic issues. J Pediatr 1999; 135: 746.

8. Coulter-Mackie MB, White CT, Hurley RM, et al. Primary Hyperoxaluria Type 1. GeneReviews. http://www.ncbi.nlm.nih. gov/bookshelf/br.fcgi?book=gene \& part=ph1 (Accessed on October 72012) [cit. 2015-10-21].

9. Cochat P, Hulton SA, Acquaviva C, et al. Primary hyperoxaluria Type 1: indications for screening and guidance for diagnosis and treatment. Nephrol Dial Transplant 2012; 27: 1729.
10. Hoppe B, Groothoff JW, Hulton SA, et al. Efficacy and safety of Oxalobacter formigenes to reduce urinary oxalate in primary hyperoxaluria. Nephrol Dial Transplant 2011; 26: 3609.

11. Bergstralh EJ, Monico CG, Lieske JC, et al. Transplantation outcomes in primary hyperoxaluria. Am J Transplant 2010; 10: 2493.

12. Milliner DS. The primary hyperoxalurias: an algorithm for diagnosis. Am J Nephrol 2005; 25: 154.

13. Tesař V, Schück O, et al. Klinická nefrologie. Praha: Grada Publishing 2006: 364. 